\section{Effect of 2,4-D and CPPU on Triploid Watermelon Production and Quality}

\author{
Maria Victoria Huitrón, Manuel Diaz, Fernando Diánez, and \\ Francisco Camacho ${ }^{1}$ \\ Plant Production in Mediterranean Crop Systems Research Group, \\ Advanced Polytechnic School, University of Almeria, Almeria 04120, Spain
}

\author{
Antonio Valverde \\ Pesticide Residues Research Group, College of Experimental Sciences, \\ University of Almeria, Almeria 04120, Spain
} Additional index words. fruit set, 2,4-D, CPPU, plant bioregulators, pollination, triploid
watermelon (Citrullus lanatus Thunb.)

\begin{abstract}
Pollination is one problem with intensive seedless watermelon (Citrullus lanatus Thunb.) production under unfavorable environmental conditions (low solar radiation and temperature) due to the lowered activity of pollinating insects, such as the bee (Apis mellifera L.). An alternative to overcome these problems is the use of plant growth regulators. For this reason, experiments were conducted for 2 years in plastic greenhouses in the fields of Almeria, southwestern Spain, to evaluate the production and quality of 'Reina de corazones' triploid watermelon grafted onto RS841 rootstock (Cucurbita maxima $\times$ Cucurbita moschata). Two phytoregulators were used for the development of the ovary: 1-(2-chloro-4-pyridyl)-3-phenylurea (CPPU) and 2,4dichlorophenoxyacetic acid (2,4-D). Concentrations of CPPU evaluated were 50, 100, 150 , and $200 \mathrm{mg} \cdot \mathrm{L}^{-1}$. An application of $0.6 \mathrm{~mL}$ was applied to each ovary in addition to $4,6,8$, or $12 \mathrm{mg} \cdot \mathrm{L}^{-1}$ of 2,4-D to the foliar mass at a proportion of $1000 \mathrm{~L} \cdot \mathrm{ha}^{-1}$. Results showed that the production and number of fruit obtained with CPPU treatments were similar to what is obtained by using bees for fruit pollination. Maximum production was reached at concentrations of $100-200 \mathrm{mg} \cdot \mathrm{L}^{-1}$. Average production was $32 \%$ to $83 \%$ higher than results from $2,4-D$ at $8 \mathrm{mg} \cdot \mathrm{L}^{-1}$. The number of fruit per plant was $33 \%$ to $35 \%$ higher as well. In the first assay, a positive correlation was also observed between production and CPPU concentration. CPPU treatments had a lower accumulation of sugars than those with 2,4-D; nevertheless, both treatments showed values of commercially acceptable soluble solids.
\end{abstract}

In recent years, the cultivation of triploid watermelon in Almeria has increased significantly. The annual increase in surface area expanded to this crop has been maintained (Fig. 1). The efficacy of grafting to control soil-borne diseases (Fusarium oxysporum $\mathrm{f}$. sp. niveum) is one of the main causes of this increase. Another reason for this growth is the introduction of triploid varieties, giving rise to seedless fruit, which is increasingly valued in European Union markets. In 2005, the surface area cultivated under plastic houses in Almeria was 6000 ha. For triploid watermelon production, the female flower should be pollinated by pollen from a diploid $(2 n)$ cultivar to obtain fruit. Early production of watermelon in plastic houses is transplanted between the months of November and February in Almeria, using between $25 \%$ and $40 \%$ of the pollinating diploid variety. This fact implies the harvest of at least $25 \%$ of seed-bearing fruit, which is less valued by the market, so that the producer receives a lower price for it (Camacho and Fernandez, 2000).

\footnotetext{
Received for publication 23 Nov. 2006. Accepted for publication $10 \mathrm{Jan} .2007$.

${ }^{1}$ To whom reprint requests should be addressed; e-mail fcamacho@ual.es.
}

Pollination is the main problem in the production of watermelon in plastic houses due to the limited activity of bees (Apis mellifera) when climatic conditions are unfavorable, such as insufficient solar radiation and temperature (Camacho and Fernandez, 2000; Hayata and Niimi, 1995; Hayata et al., 2000). Under such conditions, pollinator activity is slow and anther dehiscence is inhibited (Hayata et al., 1995; Tsukahara, 1988). It is of utmost importance in watermelon pollination that at least 1000 grains of pollen be regularly deposited on the three stigma lobes to obtain uniform fruit. Because pollen grain produces pollen tubes with descending growth and reduced lateral movement, an insufficient quantity of pollen on the stigma lobe gives rise to asymmetrical fruit. Therefore, saturation becomes an important consideration in insect pollination because uniform fruit must be obtained (McGregor, 1976).

When climatic conditions are unfavorable, flower abortion becomes a serious problem in the commercial production of cucurbits, in spite of artificial pollination (Yu, 1999). Fruit set in melon, watermelon, cucumber, and Chinese white-flowered gourd (Lagenaria leucantha) decreases in such unfavorable climatic conditions as low temperatures and cloudy or rainy days (Hayata et al., 2000, 2001; Ogawa et al., 1977; $\mathrm{Yu}, 1999)$. Under unfavorable climatic conditions, watermelon fruit set is a serious problem, which is not completely solved by using artificial pollination or increasing the number of beehives (Camacho and Fernandez, 2000).

Triploid cultivars are difficult to manage, so fruit set is more susceptible to low temperatures and other environmental stresses than in diploid cultivars (Miguel et al., 2004). Diploid cultivars require the visit of at least 6-8 bees for good fruit set (Adlerz, 1966; Stanghellini et al., 1997). The number of bee visits required for triploid cultivar fruit set, where the relationship of unviable pollen in the crop is at least $2: 1$, has not yet been determined (Stanghellini et al., 2002). Reduced fruit set in triploid watermelon crops is sometimes the consequence of inadequate plant distribution during transplanting, or it might also be associated with synchronization errors between the maturity of the diploid pollen and the triploid ovary (Camacho et al., 2003; Miguel et al., 2001b).

Plant bioregulators are an alternative to natural pollination in numerous crops. Parthenocarpy, the development of the ovary into fruit without fertilization or seed formation, is an alternative route for achieving fruit set and normal fruit development (Lukyanenko, 1991). Various research papers have shown that the application of plant growth regulators such as auxins, gibberellins, and cytokinins can improve fruit set and development: 1-(2-chloro-4-pyridyl)-3-phenylurea (CPPU) and gibberellic acid $\left(\mathrm{GA}_{3}\right)$ in grape (Retamales et al., 1995); CPPU in kiwi (Antognozzi et al., 1996; Lewis et al., 1996); naphthalene acetic acid (NAA) and phenothiol in loquat (Amoros et al., 2004); and CPPU, 2,4-dichlorophenoxyacetic acid (2,4D), and benzyl adenine (BA) in apple (Costa et al., 2004; Greene, 2001; Percy et al., 1998; Tartarini et al., 1993).

Applying plant growth regulators has been studied in cucurbit crops: CCPU, BA, and 2,4-dichlorophenoxyacetic ( $p$-chlorophenoxyacetic) acid ( $p$-CPA) in melon (Hayata et al., 2002; Li et al., 2002); CPPU in Chinese white-flowered gourd (L. leucantha) (Yu et al., 2001); CPPU, BA, 4-CPA, and $\mathrm{GA}_{3}$ in cucumber (Kim et al., 1992); BA and CPPU in watermelon (Hayata and Niimi, 1995; Hayata et al., 1995); and 2,4-D in watermelon (Camacho et al., 2003; Miguel et al., 1999). NAA, $p$-CPA, and BA were the most effective. Although ineffective at low temperatures, $\mathrm{p}-\mathrm{CPA}$ and $\mathrm{BA}$ are normally used (Hayata et al., 2000). CPPU is a new plant growth regulator that promotes fruit set and growth under unfavorable conditions for pollination and fertilization (Hayata et al., 2002).

CPPU and 2,4-D plant growth regulators were tested in outdoor watermelon crops in Valencia (eastern Spain). Fruit set and development of triploid watermelon grafted onto Shintoza (Cucurbita maxima $\times$ Cucurbita moschata) was improved by the application of 8 and $100 \mathrm{mg} \cdot \mathrm{L}^{-1}$ of 2,4-D and CPPU, 


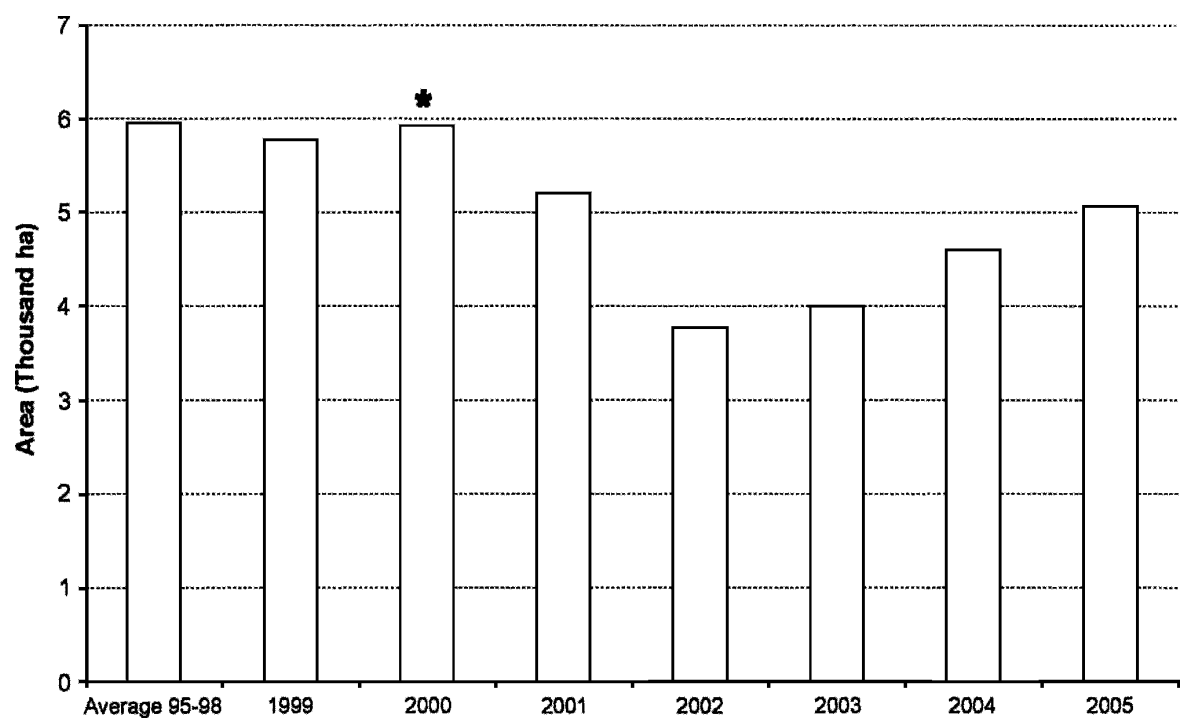

Fig. 1. Almeria watermelon area (*CVYV new virus detected in the area).

respectively (Miguel et al., 2001a, 2001b). CPPU and 2,4-D were also tested for watermelon crops in plastic houses in Almeria (southeastern Spain). The highest yields were obtained in the Sweet Marvel diploid cultivar by using CPPU at $200 \mathrm{mg} \cdot \mathrm{L}^{-1}$ (Camacho et al., 2003). Therefore, the object of this study was to evaluate the effect of CPPU and 2,4-D on fruit set, development, and quality in the 'Reina de corazones' triploid cultivar grafted onto 'RS841' (C. maxima $\times C$. moschata) and grown in plastic houses.

\section{Materials and Methods}

Plant material. Experiments were conducted during two crop cycles (spring of 2003 and 2004), in the plastic house horticultural production area of Almeria. The plant material used was watermelon (Citrullus lanatus cv. Reina de corazones), of uniform performance, productive, striped rind, and slightly oblong (Maroto et al., 2002), grafted onto 'RS841' rootstock $(C$. maxima $\times C$. moschata). It was transplanted into modified soil, locally known as "suelo arenado" (sand-covered soil) with $8.7 \mathrm{pH}$ and $3.62 \%$ organic material content. An Almeriatype, "raspa y amagado" (covered skeleton structure), commercial plastic house was used, with an 800-gauge wide trithermal polyethylene covering and zenith and lateral antiaphid, 40-mesh ventilation. Fertilization was applied by fertigation with an automatic head. Quantities of $\mathrm{N}, \mathrm{P}_{2} \mathrm{O}_{5}$, and $\mathrm{K}_{2} \mathrm{O}$ equivalent to 200,150 , and $350 \mathrm{~kg} \cdot \mathrm{ha}^{-1}$, respectively, were distributed according to crop phenological stage and as recommended by Camacho and Fernandez (2000).

Randomized complete-block design was used with four repetitions the first year and with three in the second year. In both cases, the $y_{i j}=\mu_{i j}+\tau_{i j}+\beta_{i j}+\varepsilon_{i j}$ linear additive model was followed, where $i=1,2, \ldots, 6$ for both assays; $j=1,2,3,4$ for the first season; and $j=1,2,3$ for the second season.
The test lot had a surface area of 896 and $504 \mathrm{~m}^{2}$, respectively, for the first and second years. The number of plants per elemental lot was 8 or 6 , planted at a density of 0.25 plants $/ \mathrm{m}^{2}$.

Plant growth regulator evaluated. The products used for fruit set were Sitofex (liquid formulation of BASF, Limburgerhof, Germany) and Antidrop (Agrodan), which contain synthetic phytoregulators. The concentration of Sitofex was $1 \%(\mathrm{w} / \mathrm{v})$ CPPU, from the cytokinin group. The concentration of Antidrop, of the auxin group, was 3.2\% (w/v) 2,4-D amino salt. Treatments were defined by the concentrations of the a.i.: $4,6,8$, and 12 $\mathrm{mg} \cdot \mathrm{L}^{-1}$ of $2,4-\mathrm{D}$ and $50,100,150$, and $200 \mathrm{mg} \cdot \mathrm{L}^{-1}$ of CPPU. In the second-year trial, the $50 \mathrm{mg} \cdot \mathrm{L}^{-1} \mathrm{CPPU}$ treatment was not done but was replaced with a $150 \mathrm{mg} \cdot \mathrm{L}^{-1} \mathrm{CPPU}$ treatment, due to adjustments for obtaining more uniform quality parameters after seeing first-year results. A surfactant (alkyl polyglycol at $20 \%$ w/v S.L. Mojante Inagra at a concentration of $50 \mathrm{~mL} \cdot \mathrm{hL}^{-1}$ of the commercial product) and a foliar fertilizer ( $20 \%$ to $27.8 \%$ SC. Goemar BM86 seaweed from Aragonesa at a $200 \mathrm{~mL} \cdot \mathrm{hL}^{-1}$ concentration of the commercial product) were added to the various 2,4-D solutions. They were applied on the entire foliar mass $51 \mathrm{~d}$ after transplant (dat) in the first year of the experiment and 59 dat in the second year, at a proportion of $1000 \mathrm{~L} \cdot \mathrm{ha}^{-1}$, by means of a backpack sprayer. CPPU treatments were carried out at 51 and 59 dat the first year and in the second year, every $4 \mathrm{~d}$ starting from 44 dat until five applications were made. The applicator was a manual nebulizer regulated to apply only $0.6 \mathrm{~mL}$ of solution on each ovary. Both types of phytoregulators were applied when the petals were fully opened.

Plastic houses where the tests were conducted were sealed to prevent entry by outside pollinators. Only triploid watermelon was planted for both experiments with the aim of eliminating diploid watermelon pollen in the plant vicinity. Table 1 summarizes the phytoregulators and concentrations used.

Variables evaluated. To determine production parameters, eight plants from each experimental unit were evaluated the first year and six plants the second. The parameters evaluated were total soluble solids, $\mathrm{pH}$, pulp firmness, size of pistil scar, rind thickness, longitudinal perimeter (LP), transverse perimeter (TP), and the longitudinal-transverse perimeter relationship (LP/TP). Fruit was harvested at 98 dat in the first experiment and at 106 and 114 dat in the second one. The number of fruit and their corresponding weight were recorded to determine total production, average fruit weight, and the number of fruit per plant. Three fruit were also chosen at random per repetition for quality measurements. Quality parameters evaluated were pulp firmness, total soluble solids, and $\mathrm{pH}$. Pulp firmness was represented as the average of three different places from a transverse cut in the fruit and was carried out with an FT-327 penetrometer (Bertuzzi, Facchini, Italy) with a $1-\mathrm{cm}^{2}$ probe and a scale of 0 to $13 \mathrm{~kg}$. Soluble solids content was determined as ${ }^{\circ}$ Brix. The total soluble solids content was measured with an ATC-1E refractometer (Atago, Tokyo), with a scale of 0 to $35^{\circ}$ Brix and a precision of \pm 0.2 . The $\mathrm{pH}$ was measured by an HI-9811 $\mathrm{pH}$ meter (Mitutoyo UK, Andover, U.K.), with a precision of \pm 0.2 unit. A 500-191u Digimatic caliper (Mitutoyo, Andover, U.K.) was used for measuring rind width and size of the pistil scar $(0-150-\mathrm{mm}$ measurement interval and $0.02-\mathrm{mm}$ resolution)

Climatic conditions were monitored throughout the experiment. Temperature and relative humidity were recorded every 15 min with a HOBO Pro RH/Temp H08032-08 data-logger (Onset Computer Corp.).

Table 1. Phytoregulators and their concentrations and numbers of repetitions and plants per experimental unit.

\begin{tabular}{|c|c|c|c|c|}
\hline \multirow[b]{2}{*}{ Treatment and concn $\left(\mathrm{mg} \cdot \mathrm{L}^{-1}\right)$} & \multicolumn{2}{|c|}{ First season (2003) } & \multicolumn{2}{|c|}{ Second season (2004) } \\
\hline & $\begin{array}{c}\text { No. of } \\
\text { repetitions }\end{array}$ & $\begin{array}{l}\text { No. of plants } \\
\text { per repetition }\end{array}$ & $\begin{array}{c}\text { No. of } \\
\text { repetitions }\end{array}$ & $\begin{array}{l}\text { No. of plants } \\
\text { per repetition }\end{array}$ \\
\hline \multicolumn{5}{|l|}{$\overline{\mathrm{CPPU}}$} \\
\hline 200 & 4 & 8 & 3 & 6 \\
\hline 150 & - & - & 3 & 6 \\
\hline 100 & 4 & 8 & 3 & 6 \\
\hline 50 & 4 & 8 & - & - \\
\hline \multicolumn{5}{|l|}{$2,4-\mathrm{D}$} \\
\hline 12 & 4 & 8 & 3 & 6 \\
\hline 8 & 4 & 8 & 3 & 6 \\
\hline 6 & 4 & 8 & 3 & 6 \\
\hline 4 & 4 & 8 & 3 & 6 \\
\hline
\end{tabular}


Statistical analysis. Data were subjected to analysis of variance and the separation of measurements through Fisher's least significant difference procedure $(P<0.05)$.

Lineal regression analysis $\left(Y=\beta_{0}+\beta_{1} X\right)$ was done following the next procedure: estimating the unknown parameters $\beta_{0}$ and $\beta_{1}$ using the least-squares method and checking if the models are adequate and valid.

All statistical analyses were carried out with the Statgraphics Plus 4.0 for Windows statistical program.

\section{Results}

Production. CPPU applied to the ovary at anthesis and 2,4-D applied by spraying the leaves promoted growth of fruit from unpollinated triploid watermelon flowers in crops in plastic houses. The effects of various treatments and concentrations of 2,4-D and CPPU on watermelon production in both experiments are shown on Tables 2 and 3 . Total production from both experiments was greater in blocks treated with CPPU than in those treated with 2,4-D, as is shown in Tables 8 and 9. But the differences between CPPU and 2,4-D were insignificant for concentration, except for $12 \mathrm{mg} \cdot \mathrm{L}^{-1}$. The lowest production values were from blocks treated with $12 \mathrm{mg} \cdot \mathrm{L}^{-1}$ of $2,4-\mathrm{D}$.

Quality parameters. Results from the analysis of quality parameters are shown on Tables 4, 5, 6, 7, 10, 11, 12, and 13. There were significant differences in the soluble solids content among treatments in the first experiment but not in the second one. Soluble solids contents always had higher values than the minimum acceptable market values for all watermelons $\left(8^{\circ}\right.$ Brix $)$.

Average $\mathrm{pH}$ values of fruit at harvest were between $5.37 \pm 0.18$ and $5.14 \pm 0.12$ for the first and second experiments, respectively. There were statistically significant differences among average $\mathrm{pH}$ only in the first study, with a 5.23-5.60 and 5.04-5.29 pH interval for fruit from the first and second experiments. Pulp firmness values varied from 2.53 to $3.15 \mathrm{~kg} \cdot \mathrm{cm}^{-2}$ and 1.96 to $2.22 \mathrm{~kg} \cdot \mathrm{cm}^{-2}$ for the first and second experiments, respectively, with average values of $2.88 \pm 0.31$ and $2.07 \pm 0.13 \mathrm{~kg} \cdot \mathrm{cm}^{-2}$.

Results from size of the pistil scar showed statistically significant differences between 2,4-D and CPPU, with lower values corresponding to CPPU. Measurement averages were 14.21 and $12.60 \mathrm{~mm}$ for 2,4-D and CPPU, respectively, in the first experiment and 20.97 and $12.97 \mathrm{~mm}$ for 2,4-D and CPPU in the second experiment.

Average rind thickness measurements oscillated between $16.88 \pm 1.71$ and $14.51 \pm$ $1.55 \mathrm{~mm}$ for the first and second assays, respectively. There were statistically significant differences between some 2,4-D treatments and CPPU treatments.

There were no statistically significant differences between values from the LP/TP relationship (longitudinal perimeter/transverse perimeter) because the fruit is oblong in shape.

Table 2. Effect of 2,4-D and CPPU concentration on production and on main yield components in Reina de corazones cv. triploid watermelon; first experiment (Spring 2003). ${ }^{\mathrm{z}}$

\begin{tabular}{|c|c|c|c|c|}
\hline \multirow[b]{2}{*}{ Treatment and concn $\left(\mathrm{mg} \cdot \mathrm{L}^{-1}\right)$} & \multicolumn{2}{|c|}{ Total production } & \multirow[b]{2}{*}{ Fruit/plant } & \multirow{2}{*}{$\begin{array}{l}\text { Avg fruit } \\
\text { wt (kg) }\end{array}$} \\
\hline & $\overline{\left(\mathrm{kg} \cdot \mathrm{m}^{-2}\right)}$ & $\mathrm{kg} /$ plant & & \\
\hline \multicolumn{5}{|l|}{ CPPU } \\
\hline 200 & $9.6 \mathrm{a}$ & $38.6 \mathrm{a}$ & $7.1 \mathrm{a}$ & $5.5 \mathrm{ab}$ \\
\hline 100 & $9.3 \mathrm{ab}$ & $37.1 \mathrm{ab}$ & $7.1 \mathrm{a}$ & $5.0 \mathrm{ab}$ \\
\hline 50 & $8.4 \mathrm{ab}$ & $33.8 \mathrm{ab}$ & $6.4 \mathrm{a}$ & $5.3 \mathrm{ab}$ \\
\hline \multicolumn{5}{|l|}{$2,4-\mathrm{D}$} \\
\hline 12 & $2.1 \mathrm{~d}$ & $8.4 \mathrm{~d}$ & $2.1 \mathrm{c}$ & $4.1 \mathrm{c}$ \\
\hline 8 & $7.4 \mathrm{abc}$ & $29.5 \mathrm{abc}$ & $5.1 \mathrm{ab}$ & $5.8 \mathrm{a}$ \\
\hline 6 & $6.4 \mathrm{bc}$ & $25.5 \mathrm{bc}$ & $5.5 \mathrm{a}$ & $4.6 \mathrm{bc}$ \\
\hline 4 & $6.9 \mathrm{abc}$ & $27.6 \mathrm{abc}$ & $5.1 \mathrm{ab}$ & $5.4 \mathrm{ab}$ \\
\hline
\end{tabular}

${ }^{\mathrm{z}}$ Different letters mean significant differences, at $P<0.05$. Untreated control groups were unproductive and therefore are not shown in the table.

Table 3. Effect of 2,4-D and CPPU concentration on production and on main yield components in Reina de corazones cv. triploid watermelon; second experiment (Spring 2004). ${ }^{\mathrm{T}}$

\begin{tabular}{lcccc}
\hline $\begin{array}{l}\text { Treatment and } \\
\text { concn }\left(\mathrm{mg} \cdot \mathrm{L}^{-1}\right)\end{array}$ & \multicolumn{2}{c}{ Total production } & & Avg fruit wt \\
\cline { 2 - 3 }$\left.(\mathrm{kg}) \mathrm{m}^{-2}\right)$ & $\mathrm{kg} / \mathrm{plant}$ & & Fruit/plant & $\begin{array}{c} \\
\text { CPPU }\end{array}$ \\
200 & $9.7 \mathrm{a}$ & $38.7 \mathrm{a}$ & $8.6 \mathrm{a}$ & $4.5 \mathrm{a}$ \\
150 & $8.5 \mathrm{a}$ & $36.0 \mathrm{a}$ & $8.0 \mathrm{a}$ & $4.5 \mathrm{a}$ \\
100 & $9.8 \mathrm{a}$ & $39.3 \mathrm{a}$ & $8.8 \mathrm{a}$ & $4.5 \mathrm{a}$ \\
$2,4-\mathrm{D}$ & & & & \\
12 & $5.3 \mathrm{~b}$ & $21.3 \mathrm{~b}$ & $3.9 \mathrm{~b}$ & $5.4 \mathrm{a}$ \\
8 & $5.4 \mathrm{~b}$ & $23.1 \mathrm{~b}$ & $4.3 \mathrm{~b}$ & $5.4 \mathrm{a}$ \\
6 & $5.1 \mathrm{~b}$ & $20.4 \mathrm{~b}$ & $3.7 \mathrm{~b}$ & $5.6 \mathrm{a}$ \\
4 & $3.5 \mathrm{~b}$ & $13.8 \mathrm{~b}$ & $3.0 \mathrm{~b}$ & $4.6 \mathrm{a}$ \\
\hline
\end{tabular}

${ }^{\mathrm{z}}$ Different letters mean significant differences, at $P<0.05$.

Table 4. Effect of 2,4-D and CPPU concentration on total soluble solids content, pH, pulp firmness, and pistil scar size in Reina de corazones cv. triploid watermelon; first experiment (Spring 2003). ${ }^{\mathrm{z}}$

\begin{tabular}{ccccc}
\hline $\begin{array}{l}\text { Treatment and concn } \\
\left(\mathrm{mg} \cdot \mathrm{L}^{-1}\right)\end{array}$ & ${ }^{\circ}$ Brix & $\mathrm{pH}$ & $\begin{array}{c}\text { Pulp firmness } \\
\left(\mathrm{kg} \cdot \mathrm{cm}^{-2}\right)\end{array}$ & $\begin{array}{c}\text { Pistil scar } \\
(\mathrm{mm})\end{array}$ \\
\hline CPPU & & & & \\
200 & $9.2 \mathrm{c}$ & $5.2 \mathrm{c}$ & $3.0 \mathrm{abc}$ & $13.9 \mathrm{bc}$ \\
100 & $10.1 \mathrm{~b}$ & $5.4 \mathrm{bc}$ & $2.6 \mathrm{~cd}$ & $11.8 \mathrm{~cd}$ \\
50 & $10.7 \mathrm{ab}$ & $5.3 \mathrm{c}$ & $2.8 \mathrm{bcd}$ & $12.1 \mathrm{~cd}$ \\
$2,4-\mathrm{D}$ & & & & \\
12 & $10.8 \mathrm{ab}$ & $5.4 \mathrm{bc}$ & $3.0 \mathrm{ab}$ & $11.2 \mathrm{~d}$ \\
8 & $11.0 \mathrm{a}$ & $5.4 \mathrm{~b}$ & $3.1 \mathrm{abc}$ & $16.6 \mathrm{a}$ \\
6 & $10.6 \mathrm{ab}$ & $5.3 \mathrm{bc}$ & $2.5 \mathrm{~d}$ & $14.4 \mathrm{ab}$ \\
4 & $11.0 \mathrm{a}$ & $5.6 \mathrm{a}$ & $3.2 \mathrm{ab}$ & $14.6 \mathrm{ab}$ \\
\hline
\end{tabular}

${ }^{2}$ Different letters mean significant differences, at $P<0.05$.

Table 5. Effect of 2,4-D and CPPU concentration on total soluble solids content, $\mathrm{pH}$, pulp firmness, and pistil scar size in Reina de corazones cv. triploid watermelon; second experiment (Spring 2004). ${ }^{\mathrm{z}}$

\begin{tabular}{ccccc}
\hline $\begin{array}{l}\text { Treatment and concn } \\
\left(\mathrm{mg} \cdot \mathrm{L}^{-1}\right)\end{array}$ & ${ }^{\circ}$ Brix & $\mathrm{pH}$ & $\begin{array}{c}\text { Pulp firmness } \\
\left(\mathrm{kg} \cdot \mathrm{cm}^{-2}\right)\end{array}$ & $\begin{array}{c}\text { Pistil scar } \\
(\mathrm{mm})\end{array}$ \\
\hline CPPU & $10.8 \mathrm{a}$ & $5.0 \mathrm{a}$ & $2.1 \mathrm{ab}$ & $12.7 \mathrm{~cd}$ \\
200 & $10.5 \mathrm{a}$ & $5.0 \mathrm{a}$ & $2.2 \mathrm{a}$ & $14.7 \mathrm{c}$ \\
150 & $10.8 \mathrm{a}$ & $5.1 \mathrm{a}$ & $2.0 \mathrm{~b}$ & $11.5 \mathrm{~d}$ \\
100 & & & & \\
$2,4-\mathrm{D}$ & $10.2 \mathrm{a}$ & $5.2 \mathrm{a}$ & $2.0 \mathrm{ab}$ & $21.5 \mathrm{ab}$ \\
12 & $10.6 \mathrm{a}$ & $5.2 \mathrm{a}$ & $2.1 \mathrm{ab}$ & $23.1 \mathrm{a}$ \\
8 & $10.3 \mathrm{a}$ & $5.3 \mathrm{a}$ & $2.0 \mathrm{ab}$ & $20.4 \mathrm{ab}$ \\
6 & $10.7 \mathrm{a}$ & $5.1 \mathrm{a}$ & $2.1 \mathrm{ab}$ & $18.9 \mathrm{~b}$ \\
4
\end{tabular}

${ }^{\mathrm{z}}$ Different letters mean significant differences, at $P<0.05$.

Temperature and relative humidity. Climatic unfavorable conditions for fruit set were detected during both years' assays. Temperature and relative humidity showed important oscillations during fruit set time (Fig. 2).

\section{Discussion}

Production. In the first experiment, except for treatment with $12 \mathrm{mg} \cdot \mathrm{L}^{-1}$ of
2,4-D, average production corresponding to CPPU treatments exceeded those with 2,4-D by $32.5 \%$. A positive relationship was also observed between total production and CPPU concentration; that is, the greater the concentration, the higher the production. A maximum value was obtained at $200 \mathrm{mg} \cdot \mathrm{L}^{-1}$ of CPPU, contrary to what happened with the highest concentration of $2,4-\mathrm{D}$. 
Table 6. Effect of 2,4-D and CPPU concentration on rind thickness, longitudinal perimeter (LP), transverse perimeter (TP), and LP/TP relationship in Reina de corazones cv. triploid watermelon; first experiment (Spring 2003). ${ }^{\mathrm{Z}}$

\begin{tabular}{lcccc}
\hline $\begin{array}{l}\text { Treatment and concn } \\
\left(\mathrm{mg} \cdot \mathrm{L}^{-1}\right)\end{array}$ & $\begin{array}{c}\text { Rind thickness } \\
(\mathrm{mm})\end{array}$ & LP $(\mathrm{cm})$ & TP $(\mathrm{cm})$ & LP/TP \\
\hline CPPU & $16.4 \mathrm{ab}$ & $71.5 \mathrm{a}$ & $65.1 \mathrm{a}$ & $1.1 \mathrm{a}$ \\
200 & $15.3 \mathrm{~b}$ & $69.3 \mathrm{a}$ & $63.8 \mathrm{ab}$ & $1.1 \mathrm{a}$ \\
100 & $16.0 \mathrm{ab}$ & $71.6 \mathrm{a}$ & $63.7 \mathrm{ab}$ & $1.1 \mathrm{a}$ \\
50 & & & & \\
$2,4-\mathrm{D}$ & $16.7 \mathrm{ab}$ & $63.4 \mathrm{~b}$ & $58.7 \mathrm{c}$ & $1.1 \mathrm{a}$ \\
12 & $16.7 \mathrm{ab}$ & $72.9 \mathrm{a}$ & $66.0 \mathrm{c}$ & $1.1 \mathrm{a}$ \\
8 & $18.2 \mathrm{a}$ & $68.5 \mathrm{a}$ & $59.9 \mathrm{bc}$ & $1.1 \mathrm{a}$ \\
6 & $18.7 \mathrm{a}$ & $68.7 \mathrm{a}$ & $61.7 \mathrm{abc}$ & $1.1 \mathrm{a}$ \\
4
\end{tabular}

${ }^{\mathrm{z}}$ Different letters mean significant differences, at $P<0.05$.

Table 7. Effect of 2,4-D and CPPU concentration on rind thickness, longitudinal perimeter (LP), transverse perimeter (TP), and LP/TP relationship in Reina de corazones cv. triploid watermelon; second experiment (Spring 2004). ${ }^{\mathrm{Z}}$

\begin{tabular}{lcccc}
\hline $\begin{array}{l}\text { Treatment and concn } \\
\left(\mathrm{mg} \cdot \mathrm{L}^{-1}\right)\end{array}$ & $\begin{array}{c}\text { Rind thickness } \\
(\mathrm{mm})\end{array}$ & LP $(\mathrm{cm})$ & TP $(\mathrm{cm})$ & LP/TP \\
\hline CPPU & & & & \\
200 & $13.6 \mathrm{~b}$ & $70.5 \mathrm{a}$ & $66.6 \mathrm{a}$ & $1.1 \mathrm{a}$ \\
150 & $13.7 \mathrm{~b}$ & $69.9 \mathrm{a}$ & $65.8 \mathrm{a}$ & $1.1 \mathrm{a}$ \\
100 & $14.0 \mathrm{~b}$ & $71.5 \mathrm{a}$ & $67.9 \mathrm{a}$ & $1.1 \mathrm{a}$ \\
$2,4-\mathrm{D}$ & & & & \\
12 & $16.7 \mathrm{a}$ & $73.2 \mathrm{a}$ & $69.2 \mathrm{a}$ & $1.1 \mathrm{a}$ \\
8 & $14.8 \mathrm{~b}$ & $70.9 \mathrm{a}$ & $68.0 \mathrm{a}$ & $1.0 \mathrm{a}$ \\
6 & $14.9 \mathrm{~b}$ & $71.6 \mathrm{a}$ & $67.6 \mathrm{a}$ & $1.1 \mathrm{a}$ \\
4 & $14.0 \mathrm{~b}$ & $70.8 \mathrm{a}$ & $67.3 \mathrm{a}$ & $1.0 \mathrm{a}$ \\
\hline
\end{tabular}

${ }^{\mathrm{z}}$ Different letters mean significant differences, at $P<0.05$.

Table 8. Effect of 2,4-D and CPPU treatment on production and on main yield components in Reina de corazones cv. triploid watermelon; first experiment (Spring 2003). ${ }^{\mathrm{z}}$

\begin{tabular}{|c|c|c|c|c|}
\hline \multirow[b]{2}{*}{ Treatment } & \multicolumn{2}{|c|}{ Total production } & \multirow[b]{2}{*}{ Fruit/plant } & \multirow{2}{*}{$\begin{array}{l}\text { Avg fruit wt } \\
(\mathrm{kg})\end{array}$} \\
\hline & $\overline{\left(\mathrm{kg} \cdot \mathrm{m}^{-2}\right)}$ & $\overline{\mathrm{kg} / \mathrm{plant}}$ & & \\
\hline$\overline{\mathrm{CPPU}}$ & $9.1 \mathrm{a}$ & $36.5 \mathrm{a}$ & $6.9 \mathrm{a}$ & $5.3 \mathrm{a}$ \\
\hline $2,4-\mathrm{D}$ & $5.7 \mathrm{~b}$ & $22.8 \mathrm{~b}$ & $4.5 \mathrm{~b}$ & $5.0 \mathrm{a}$ \\
\hline
\end{tabular}

${ }^{\mathrm{z}}$ Different letters mean significant differences, at $P<0.05$.

Table 9. Effect of 2,4-D and CPPU treatment on production and on main yield components in Reina de corazones cv. triploid watermelon; second experiment (Spring 2004). ${ }^{2}$

\begin{tabular}{lcccc}
\hline & \multicolumn{2}{c}{ Total production } & & \multicolumn{2}{c}{ Avg fruit wt } \\
\cline { 2 - 5 } Treatment & $\left(\mathrm{kg} \cdot \mathrm{m}^{-2}\right)$ & $\mathrm{kg} / \mathrm{plant}$ & Fruit/plant & $8.5 \mathrm{a}$ \\
\hline CPPU & $9.3 \mathrm{a}$ & $38.0 \mathrm{a}$ & $8.5 \mathrm{a}$ & $5.3 \mathrm{a}$ \\
\hline
\end{tabular}

${ }^{\mathrm{z}}$ Different letters mean significant differences, at $P<0.05$.

Table 10. Effect of 2,4-D and CPPU treatment on total soluble solids content, $\mathrm{pH}$, pulp firmness, and size of pistil scar in Reina de corazones cv. triploid watermelon; first experiment (Spring 2003). ${ }^{\mathrm{B}}$

\begin{tabular}{lcccc}
\hline Treatment & ${ }^{\circ}$ Brix & $\mathrm{pH}$ & $\begin{array}{c}\text { Pulp firmness } \\
\left(\mathrm{kg} \cdot \mathrm{cm}^{-2}\right)\end{array}$ & $\begin{array}{c}\text { Pistil scar } \\
(\mathrm{mm})\end{array}$ \\
\hline CPPU & $10.0 \mathrm{a}$ & $5.3 \mathrm{a}$ & $2.8 \mathrm{a}$ & $12.6 \mathrm{~b}$ \\
$2,4-\mathrm{D}$ & $10.9 \mathrm{a}$ & $5.4 \mathrm{a}$ & $3.1 \mathrm{a}$ & $15.2 \mathrm{a}$ \\
\hline
\end{tabular}

${ }^{\mathrm{z}}$ Different letters mean significant differences, at $P<0.05$.

Table 11. Effect of 2,4-D and CPPU treatment on total soluble solids content, $\mathrm{pH}$, pulp firmness, and size of pistil scar in Reina de corazones cv. triploid watermelon; second experiment (Spring 2004). ${ }^{z}$

\begin{tabular}{lcccc}
\hline Treatment & ${ }^{\circ}$ Brix & $\mathrm{pH}$ & $\begin{array}{c}\text { Pulp firmness } \\
\left(\mathrm{kg} \cdot \mathrm{cm}^{-2}\right)\end{array}$ & $\begin{array}{c}\text { Pistil scar } \\
(\mathrm{mm})\end{array}$ \\
\hline CPPU & $10.7 \mathrm{a}$ & $5.0 \mathrm{a}$ & $2.1 \mathrm{a}$ & $13.0 \mathrm{~b}$ \\
$2,4-\mathrm{D}$ & $10.5 \mathrm{a}$ & $5.2 \mathrm{a}$ & $2.1 \mathrm{a}$ & $21.0 \mathrm{a}$ \\
\hline
\end{tabular}

${ }^{\mathrm{z}}$ Different letters mean significant differences, at $P<0.05$.

Results from CPPU treatments are similar to those observed by Camacho and Fernandez (2000) in 1996 and 1997, respectively, for the same cultivar and stock, using bees for pollination. On the other hand, production was significantly affected by treatments.

This performance is similar to what Camacho et al. (2003) obtained with 'Sweet
Marvel' diploid watermelon grafted onto 'RS841' (C. maxima $\times$ C. moschata) in plastic houses.

In the second experiment, although it lacks a linear relationship between concentrations of CPPU and production values, the production values are still higher than those obtained with 2,4-D applications, as was observed in the first experiment.

Other researchers have reported linear performance between CPPU concentration and fruit weight (Greene, 2001), although in the case of Greene (2001) it was due to the fruit thinning effect incited by various CPPU concentrations.

In the results presented herein, a fruit set (expressed as harvested fruit compared with treated flowers) of $85.0 \%, 69.76 \%$, and $78.70 \%$ was obtained in the second experiment for CPPU concentrations of 100,150 , and $200 \mathrm{mg} \cdot \mathrm{L}^{-1}$, respectively. Incidence of split fruit was, respectively, $4.84 \%, 8.24 \%$, and $9.14 \%$ of the flowers treated per plant. Low concentrations of CPPU applications increased the number of split fruit in seedbearing as well as in seedless melon (Cucumis melo). CPPU had a great effect on seedbearing fruit set. In seedless melons, CPPU induced $100 \%$ fruit set with parthenocarpic development when $10 \mathrm{mg} \cdot \mathrm{L}^{-1}$ was applied. Lower concentrations were much less effective (Hayata et al., 2000). The effects of CPPU in watermelon fruit set under unfavorable crop conditions were reported by Hayata et al. (1995). They obtained $26.9 \%, 65.05 \%$, and $89.5 \%$ fruit set in manual pollination with 20 and $200 \mathrm{mg} \cdot \mathrm{L}^{-1}$ of CPPU, respectively.

The number of fruit per plant performed similarly to production. The strong correlation $(r=0.93)$ shown by these parameters (Fig. 3) in both seasons explains this performance and simultaneously corroborates the observations of Camacho and Fernandez (2000), in that the number of fruit per plant is the yield component with the greatest effect on productivity. Thus, production values expressed in $\mathrm{kg} \cdot \mathrm{m}^{-2}$ or in $\mathrm{kg} /$ plant for both seasons reflect the number of fruit set.

On the other hand, comparing these results with those obtained from assays conducted in Almeria by Camacho et al. (2003), fruit set in the 2002-2003 season for 50, 100, and $200 \mathrm{mg} \cdot \mathrm{L}^{-1}$ of CPPU surpassed the number of fruit set from the 'Sweet Marvel' diploid cultivar by $130 \%, 55 \%$, and $48 \%$, respectively, for these same concentrations. These percentages are even higher when considering the number of fruit set from the 2003-2004 season for concentrations of 100 and $200 \mathrm{mg} \cdot \mathrm{L}^{-1} \mathrm{CPPU}$.

Also, when compared with results from the Community of Valencia (eastern Spain), the number of fruit set with 50 and $100 \mathrm{mg} \cdot \mathrm{L}^{-1}$ of CPPU, as well as with 4 and $8 \mathrm{mg} \cdot \mathrm{L}^{-1}$ of 2,4-D in the 2002-2003 season, exceeded the values obtained by Miguel et al. (2003a, $2003 \mathrm{~b}$ ) by $100 \%$ for these concentrations in the same cultivar-stock combination in the same year.

Because the number of fruit set is one of the components directly influencing 
Table 12. Effect of 2,4-D and CPPU treatment on rind thickness, longitudinal perimeter (LP), transverse perimeter (TP), and LP/TP relationship in Reina de corazones cv. triploid watermelon; first experiment (Spring 2003). ${ }^{\mathrm{z}}$

\begin{tabular}{lcccr}
\hline & Rind thickness & & & \\
Treatment & $(\mathrm{mm})$ & LP $(\mathrm{cm})$ & TP $(\mathrm{cm})$ & LP/TP \\
\hline CPPU & $15.9 \mathrm{a}$ & $70.8 \mathrm{a}$ & $64.2 \mathrm{a}$ & $1.1 \mathrm{a}$ \\
$2,4-\mathrm{D}$ & $17.6 \mathrm{a}$ & $68.4 \mathrm{a}$ & $61.6 \mathrm{~b}$ & $1.1 \mathrm{a}$ \\
\hline
\end{tabular}

${ }^{2}$ Different letters mean significant differences, at $P<0.05$.

Table 13. Effect of 2,4-D and CPPU treatment on rind thickness, longitudinal perimeter (LP), transverse perimeter (TP), and LP/TP relationship in Reina de corazones cv. triploid watermelon; second experiment (Spring 2004). ${ }^{\mathrm{z}}$

\begin{tabular}{lcccr}
\hline & Rind thickness & & & \\
Treatment & $(\mathrm{mm})$ & LP $(\mathrm{cm})$ & TP $(\mathrm{cm})$ & LP/TP \\
\hline CPPU & $13.8 \mathrm{~b}$ & $70.6 \mathrm{a}$ & $66.8 \mathrm{a}$ & $1.1 \mathrm{a}$ \\
$2,4-\mathrm{D}$ & $15.1 \mathrm{a}$ & $71.6 \mathrm{a}$ & $68.0 \mathrm{a}$ & $1.1 \mathrm{a}$ \\
\hline
\end{tabular}

${ }^{\mathrm{z}}$ Different letters mean significant differences, at $P<0.05$.

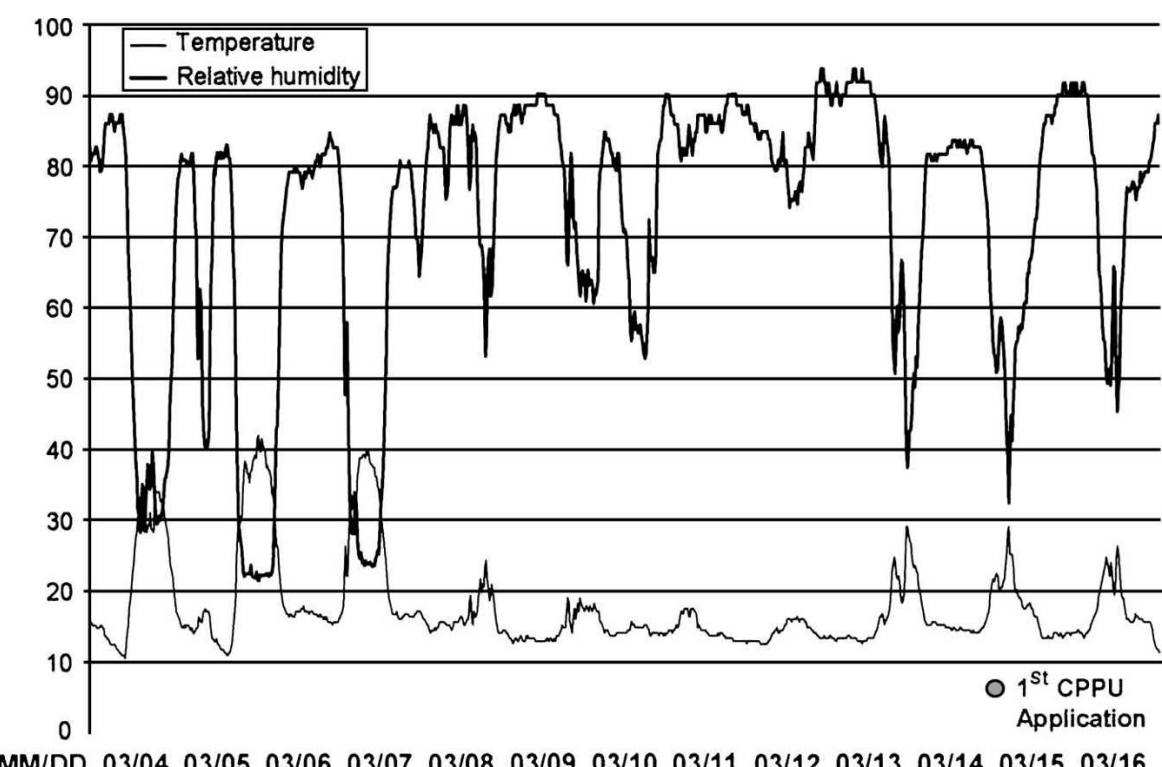

Fig. 2. Temperature $\left({ }^{\circ} \mathrm{C}\right)$ and relative humidity $(\%)$ in watermelon plastic houses during the beginning of flowering (2004).

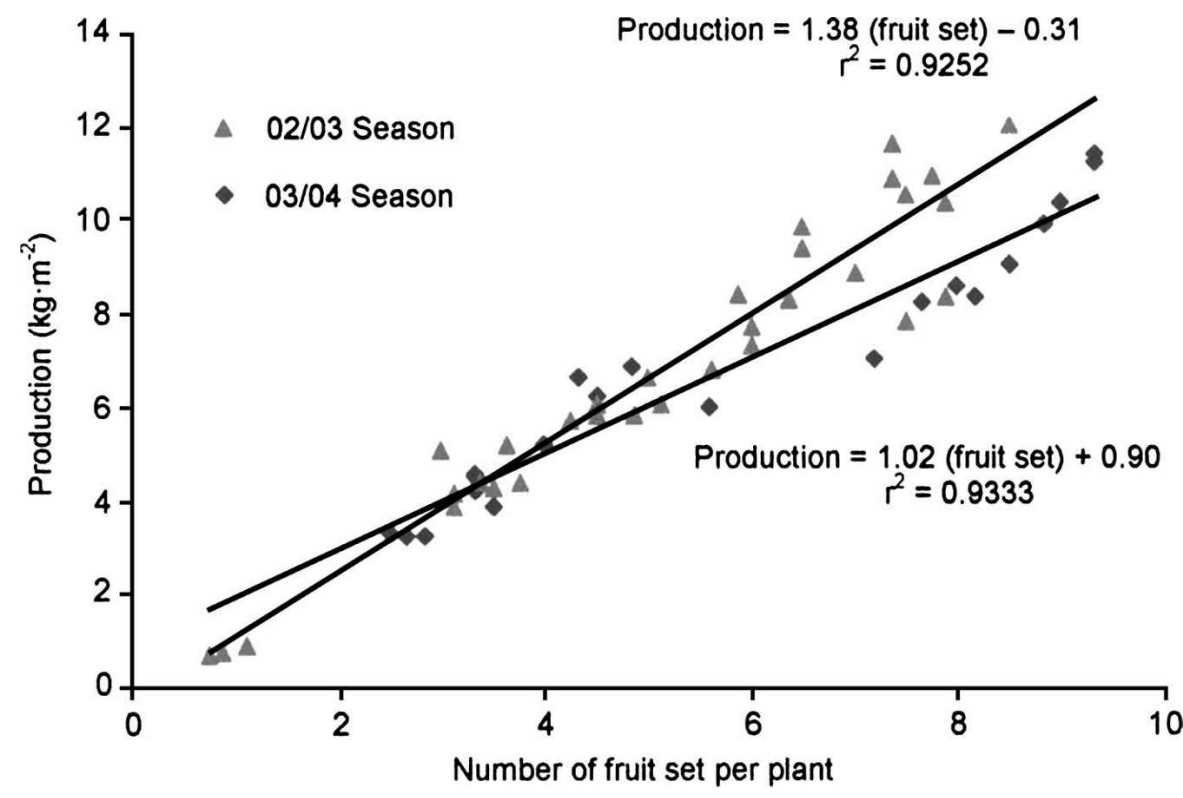

Fig. 3. Relationship between fruit set per plant and production in Reina de corazones cv. in the 2002-2003 and 2003-2004 seasons. (Both lineal models and parameters $\beta_{0}$ and $\beta_{1}$ for each year were significant for $P<0.05$. production, several researchers have tried to explain what happens in the fruit before and after this process. Talon et al. (1990) studied hormonal changes associated with fruit set and development in mandarins. Their results suggest that the fruit set potential in parthenocarpic fruit is mainly affected by their hormonal state during the late stages of cellular division and the early stages of cellular growth. Hayata et al. (2002) later affirmed that CPPU application and pollination cause high contents of indoleacetic acid (IAA) and low contents of abscisic acid (ABA) during the first stages of fruit development. These situations can be closely related to fruit set and growth, as observed in the experiments described in this article.

Quality parameters. Tables 4 and 5 show the values for content of solids ( ${ }^{\circ}$ Brix), degree of acidity $(\mathrm{pH})$, and fruit firmness.

All ${ }^{\circ}$ Brix values were within acceptable commercial requirements and were similar to those obtained by Camacho and Fernandez (2000) for the same cultivar and stock. Nevertheless, CPPU treatments showed lower ${ }^{\circ}$ Brix values compared with 2,4-D treatments. Similarly, an inverse relationship was also observed between CPPU concentration and ${ }^{\circ} \mathrm{Brix}$; that is to say, the greater the CPPU concentration, the lower the soluble solids content. Similar results were obtained in various grapevine cultivars: 'Kings Ruby' (El-Hammady et al., 2000), 'Perlette' and 'Italia' (Ezzahouani, 2000), 'Tas-A-Ganesh' (Bhujbal et al., 2002), and 'Campbell Early' (Kim et al., 2002). Hayata et al. (2000) reported that high CPPU concentrations applied to muskmelon crops reduced sucrose levels in the placenta of seedless fruit, indicating that such concentrations play a very important role in sugar accumulation during the late stages of development. In addition, Hayata et al. (2001) concluded that levels of sucrose synthase activity are closely related to sugar accumulation in seedless, parthenocarpic muskmelon.

With the increase in CPPU concentration, $\mathrm{pH}$ values decreased, as did ${ }^{\circ} \mathrm{Brix}$, an observation reported by Ezzahouani (2000) in grapevine varieties with and without seeds. The combination of ${ }^{\circ}$ Brix and $\mathrm{pH}$ values from this research indicate that, as the CPPU concentration increases, fruit ripening is delayed. NeSmith (2002) reached similar results with blueberry (Vaccinum ashei R.) as did Retamales et al. (1995) with 'Thompson Seedless' grape.

Pulp firmness values are higher with CPPU treatments $\left(2.61-2.95 \mathrm{~kg} \cdot \mathrm{cm}^{-2}\right)$ than those measured by Camacho and Fernandez (2000), which could be an effect of the ${ }^{\circ}$ Brix and $\mathrm{pH}$ values shown, with repercussions of a delay in ripening.

\section{Conclusions}

The results presented herein allow the affirmation that - in the place where these experiments were conducted - the production obtained with CPPU is similar to that obtained by using pollinator insects. CPPU 
treatments in all concentrations surpass those with 2,4-D, reaching maximum production between 100 and $200 \mathrm{mg} \cdot \mathrm{L}^{-1}$. Production and average number of fruit with CPPU treatments exceeded that obtained with 2,4-D by $32.5 \%$ and $35 \%$, respectively. All treatments showed ${ }^{\circ}$ Brix values that surpassed the required commercial minimum. However, those corresponding to CPPU showed less sugar accumulation compared with 2,4-D.

\section{Literature Cited}

Adlerz, W.C. 1966. Honey bee visit numbers and watermelon pollination. J. Econ. Entomol. 59:28-30.

Amorós, A., P. Zapata, M.A. Petrel, M.A. Botella, M.S. Almansa, and M. Serrano. 2004. Role of naphthalene acetic acid and phenothiol treatments on increasing fruit size and advancing fruit maturity in loquat. Scientia Hort. 102:387-398.

Antognozzi, E., A. Battistelli, F. Famiani, S. Moscattello, F. Stanica, and A. Tombesi. 1996. Influence of CPPU on carbohydrate accumulation and metabolism in fruits of Actinidia deliciosa (A. Chev.). Scientia Hort. 65:37-47.

Bhujbal, B., D. Ranawade, and K. Jagtap. 2002. Effects of CPPU on quality of grapes cv. Tas.AGanesh. J. Maharashtra Agr. Univ. 27:13-14.

Camacho, F. and E.J. Fernández. 2000. El cultivo de sandía apirena injertada, bajo invernadero, en el litoral mediterráneo español. Ed. Caja Rural de Almería.

Camacho, F., E.J. Fernández, and M. Pérez. 2003. Greenhouse production of diploid watermelon without biological pollination: effects of 2,4-D and CPPU on yield and seedless fruit induction. Acta Hort. 614:145-148.

Costa, G., F. Bucchi, M. Montefiori, A.M. Bregoli, and L. Corelli Grappadelli. 2004. Thinning activity and fruit quality of Gala and Fuji apple varieties as affected by cytokinins. Acta Hort. 653:107-113 (Proc. 9th Intl. Symp. Plant Bioregulators in Fruit Prod.).

El-Hammady, A.M., A.D. Shaltout, N. AbdelHamid, and M. El-Sayed. 2000. Effect of sitofex (CPPU) and shoulder thinning on yield and quality of King's Ruby grapes. Arab Univ. J. Agr. Sci. 8:735-754.

Ezzahouani, A. 2000. Effect of forchlorfenuron (CPPU) and girdling on table grape cultivars 'Perlette' and 'Italia'. J. Int. Sci. Vigne Vin 34:57-60.

Greene, D.G. 2001. CPPU influences fruit quality and abscission of 'McIntosh' apples. HortScience 36:1292-1295.

Hayata, Y., X.X. Li, D. Kishimoto, and Y. Osajima. 2001. $p$-CPA enhances growth and quality of muskmelon fruits. Plant Growth Regulat. 36:13-18.

Hayata, Y., X.X. Li, and Y. Osajima. 2002. Pollination and CPPU treatment increase endogenous IAA and decrease endogenous
ABA in muskmelons during early development. J. Amer. Soc. Hort. Sci. 127:908-911.

Hayata, Y. and Y. Niimi. 1995. Synthetic cytokinin 1-(2-chloro-4-pyridyl)-3-phenylurea (CPPU) promotes fruit set and induces parthenocarpy in watermelon. J. Amer. Soc. Hort. Sci. 120:997-1000.

Hayata, Y., Y. Niimi, and N. Iwasaki. 1995. Inducing parthenocarpy fruit of watermelon with plant bioregulators. Acta Hort. 394:235240.

Hayata, Y., Y. Niimi, K. Inoue, and S. Kondo. 2000. CPPU and BA, with and without pollination, affect set, growth and quality of muskmelon fruit. HortScience 35:868-870.

Kim, I.L., Y.L. Piao, Y.S. Hwang, and J. Lee. 2002. Effects of synthetic cytokinin, thidiazuron on berry size and quality of 'Campbell Early' (Vitis labruscana) grapes. J. Korean Soc. Hort. Sci. 43:457-461.

Kim, I.S., H. Okubo, and K. Fukeda. 1992. Endogenous levels of IIA in relation to parthenocarpy in cucumber (Cucumis sativus L.). Scientia Hort. 52:1-8.

Lewis, D.H., G.K. Burge, M.E. Hopping, and P.E. Jameson. 1996. Cytokinins and fruit development in the kiwifruit (Actinidia deliciosa). II. Effects of reduced pollination and CPPU application. Physiol. Plant. 98:187-195.

Li, X.X., Y. Hayata, and Y. Osajima. 2002 . p-CPA increases the endogenous IIA content of parthenocarpic muskmelon fruit. Plant Growth Regulat. 37:99-103.

Lukyanenko, A.N. 1991. Parthenocarpy in tomato, p. 167-178. In: G. Kalloo (ed.). Genetic improvement of tomato, Monographs on Theoretical and Applied Genetics 14. SpringerVerlag, Berlin.

Maroto, J.V., A. Miguel, and F. Pomares. 2002. El cultivo de la sandía. Caja Rural de Valencia. Ediciones Mundi-Prensa.

McGregor, S.E. 1976. Insect pollination of cultivated crop plants. Agriculture Handbook No. 496. Agricultural Research Service, U.S. Department of Agriculture, Washington, D.C.

Miguel, A., J.V. Maroto, and S. López. 2001a. Triploid seedless watermelon production without pollinators. Effect of the number of sprayed flowers on fruit size. Acta Hort. 559:135-138.

Miguel, A., J.V. Maroto, and S. López. 2001b. Production of different triploid watermelon cultivars without pollinators. Acta Hort. 559:145-148.

Miguel, A., J.V. Maroto, S. López, J. Verdú, S. García, E. Márquez, and D. Herrans. 1999. Comparación de diferentes concentraciones de CPPU en el tratamiento a flor para el cuaje de sandía triploide sin polinizador, p. 157-159. Memoria de actividades. Resultados de ensayos hortícolas. Consellería de Agricultura, Pesca i Alimentació de la Generalitat Valenciana.

Miguel, A., J.V. Maroto, A. San Bautista, C. Baixauli, V. Cebolla, B. Pascual, S. López, and J.L. Guardiola. 2004. The grafting of triploid watermelon is an advantageous alternative to soil fumigation by methyl bromide for control of Fusarium wilt. Scientia Hort. 103:9-17.

Miguel, A., J.I. Marsal, I. Verdú, J. García, J. Villalba, and V. Bosh. 2003a. Comparación de métodos de cuaje de sandia triploide en invernadero, p. 105-106. In: Memória de actividades. Resultado de ensayos hortícolas. Consellería de Agricultura, Pesca y Alimentación.

Miguel, A., J.I. Marsal, I. Verdú, J. García, J. Villalba, and V. Bosh. 2003b. Cuaje de sandia triploide sin polinizador en invernadero. Comparación de diferentes concentraciones de 2,4-D en pulverización sobre la planta, p. 107-108. In: Memória de actividades. Resultado de ensayos hortícolas. Consellería de Agricultura, Pesca y Alimentación.

NeSmith, D.S. 2002. Response of rabbiteye blueberry (Vaccinium ashei Reade) to growth regulators CPPU and gibberellic acid. HortScience 37:666-668

Ogawa, Y., N. Inoue, and S. Auki. 1977. Prominent promotion on the fruit growth in Cucumis sativus L. J. Jpn. Soc. Hort. Sci. 59: 597-601.

Percy, A.E., P.E. Jameson, and L.D. Melton. 1998. Expansion during early apple fruit development induced by auxin and $N$-(2-chloro-4pyridyl)- $N$-phenylurea: effect on cell wall hemicellulose. Plant Growth Regulat. 26:1-6.

Retamales, J., F. Bangerth, T. Cooper, and R. Callejas. 1995. Effects of CPPU and $\mathrm{GA}_{3}$ on fruit quality of Sultanina table grape. Acta Hort. 394:149-158.

Stanghellini, M.S., J.T. Ambrose, and J.R. Schultheis. 1997. The effects of honey bee and bumble bee pollination on the fruit set and abortion of cucumber and watermelon. Amer. Bee J. 137:386-391.

Stanghellini, M.S., J.R. Schultheis, and J.T. Ambrose. 2002. Pollen mobilization in selected Cucurbitaceae and the putative effects of pollinator abundance on pollen depletion rates. J. Amer. Soc. Hort. Sci. 127:729-736.

Talon, M., L. Zacarías, and E. Primo-Millo. 1990. Hormonal changes associated with fruit set and development in mandarins differing in their parthenocarpic ability. Physiol. Plant. 79:400406.

Tartarini, S., S. Sansavini, and M. Ventura. 1993. CPPU control of fruit morphogenesis in apple. Scientia Hort. 53:273-279.

Tsukahara, A. 1988. Semi-forcing culture in watermelon, p. 194-196. In: The system of agricultural technology: melon and watermelon. Soc. Cult. Agr. Vill. Press, Tokyo (in Japanese).

Yu, J.Q. 1999. Parthenocarpy induced by $N$-(2chloro-4-pyridyl)- $N^{\prime}$-phenylurea (CPPU) prevents flower abortion in Chinese whiteflowered gourd (Lagenaria leucantha). Environ. Exp. Bot. 42:121-128.

Yu, J.Q., Y. Li, Y.R. Qian, and Z.J. Zhu. 2001. Cell division and cell enlargement in fruit of Lagenaria leucantha as influenced by pollination and plant growth substances. Plant Growth Regulat. 33:117-122. 